\title{
Areas of application of the design approach: the practice of social environmental design in the mirror of sociological research
}

\author{
Elena Aleshina ${ }^{1}$, Alexey Zverev ${ }^{2, *}$, Sergey Karachkov ${ }^{3}$ \\ ${ }^{1}$ GAU DPO Yamalo-Nenets Autonomous Okrug "Regional Institute for the Development of \\ Education", Salekhard, Russia \\ ${ }^{2}$ Russian Presidential Academy of National Economy and Public Administration, Yekaterinburg, \\ Russia \\ ${ }^{3} \mathrm{PAO}$ "Ural Plant of Chemical Engineering", Yekaterinburg, Russia
}

\begin{abstract}
The article discusses the project approach, substantiates the practicality and universality of its application in various areas of management practice. The data of the sociological studies carried out by the authors of the features of participatory (involved) design in the educational environment of a general education institution, the urban environment of closed administrative-territorial entities. The possibility of applying the design approach and the concept of participatory (involved) design in various environments is analyzed: intra-organizational, local society. Research methodology: activity approach, systems approach, project approach, guide interviews of experts, mass survey. Results and conclusions: as a result of comparing the data of sociological research, the authors come to the conclusion that the project approach is a flexible tool for identifying and solving various managerial problems of the relationship between subjects and management actors in different environments. Participatory design gives results both at the organizational level (for example, high school) and at the level of urban society (ZATO).
\end{abstract}

\section{Introduction}

The main purpose of the article is to substantiate, using the example of the concepts of participatory and corporate-value design, that the project approach can be applied in various areas of social management. The project approach in modern organization management and public administration is widespread. This is how the methodological concepts of organizational design were widely used. According to B.N. Gerasimov "an important role in this was played by foreign companies, which in search of competitive technologies went beyond the limits of specific industries and the interests of specific production processes. In parallel, scientific activities began to be carried out, substantiating the main provisions of the methodology of organizational design "[1]. Here, among others, I would like to note the work of Chinese scientists L. Joo and S. Chong regarding the role

\footnotetext{
* Corresponding author: zverefff@ya.ru
} 
of design in increasing competitiveness by building up organizational innovation potential [2].

Also, B.N. Gerasimov quite rightly, in our opinion, notes the relationship between the design and the control environment. So, he writes that "the organizational design of situation management systems is dictated by the need to combine ... the characteristics of the organization with the integrating and differentiating processes of the external environment" [3].

At the level of the state, state and municipal administration in a number of socially significant areas of social functioning and development, the practice of project management in general, as well as national projects in particular, is widely used.

So, N.V. Mironenko, O. V. Leonova write that "the application of the project management system, of course, opens up many prospects for effective public administration" [4].

B.N. Porfiriev [5], O.B. Ivanov and E.M. Buchwald [6], RL Fedosova [7] and others note the importance of national projects for the development of the Russian state. On this occasion N.N. Bondarev and N.I. Komkov write: "national projects ... should serve as a guideline for the concentration of financial, material, technical and intellectual resources aimed at solving nationwide large-scale complex problems ... Methodological and organizational shortcomings in the formation of national projects pose significant risks for the successful and timely achievement of national goals" [ eight].

Development programs, for example, are also the result of a project-based approach in management practice. Often, practitioners do not separate the program and the project, understanding by them activities regulated by terms and results. So S.A. Makovkina and O. M. Trofimova give the following definition of the project: "a project is a set of interrelated activities designed to achieve within a given period of time and with a set budget of the tasks set with clear goals" [9]. This is the essence of the approach to management (see the works of the authors of the school of organizational design GP Shchedrovitsky, for example [10]).

Sociology of management and management theory have a slightly different view of the concept of project and design, in terms of such key concepts as "goal", "subject of management", "interacting actor", "stakeholder", "management information" in general and various types of knowledge. defining directions of managerial interaction between the subject and the actor, "participatory (involved) design", etc. In this case, the project is defined as a complex target image of changes in the management environment, organization, society, etc. created by the subject of management, implemented by the actor - controlled subject. There are two types of initiatives - the initiative to create an image of the future and the initiative to implement such an image in practice. Thanks to the vision of the image of the future, in accordance with it, any activity can be organized, as an activity in this direction, an appropriate structure of interactions and relationships between people, as subjects and actors of management, is formed. Thus, the project predetermines the logic and directions of the organization of human activity and the formation, change, overcoming, creation of the environment as a set of conditions for such interaction. A significant role in the formation of this theoretical concept was played by fundamental research of the information, activity essence of the phenomenon of management from the point of view and using the terminological apparatus of system theory and management theory, attempts to converge the ideas of design and social management, development of the concept and methodology for the design of social systems, etc., ( V.A.Kostin and N.B. Kostina, T.M.Dridze, B.N.Gerasimov, J. Dietrich, Zh.T. Toshchenko).

Based on the provisions of the theory and sociology of management, we believe that design is not just a management tool in an organization, but, more broadly, an approach to 
understanding the essence of directed social interaction, the formation and implementation in practice of ideas, vision of the future of communities, their relationships.

\section{Methodology}

The theoretical and methodological basis in the process of preparing these materials was the project, activity, systematic approaches.

In accordance with the activity approach, the participation of the actor, the initiator of the development of the project is a key moment in the process of social design, initiation of social change, personal development, etc. Within the framework of the systems approach, the analysis of social design involves the study of its structure and organization, as well as the interdependencies of elements and system-forming factors.

Sometimes approaches to social design from the standpoint of R. Ackoff's theory of participatory action [11] allows, in turn, to consider the project as a "project of creating opportunities" through the prism of involvement, active interaction of stakeholders in the process of designing the social environment. In this particular case, "opportunities" imply the orientation of the project to encourage the controlled subjects and actors to improve the conditions of social life, to participate in such social endeavors, inspired by this process.

The use of the aforementioned theoretical approaches predetermined the authors' understanding of the concept of the design approach. One of the types of social knowledge present in social management is prescriptive knowledge, which fixes not what is, but what should be. The study of both participatory and corporate-value design of the social environment as an integral phenomenon should be carried out from the standpoint of prescriptive knowledge. Let us consider the stated thesis about the role of prescriptive knowledge in disclosing the essence of participatory design of the social environment in more detail. Projects and goals are the forms of prescriptive knowledge. Participatory design always has a normative aspect, this is what it should be. Any project is initially potential. Not every project becomes operational. A functioning project is a specific quality of a social project. The sign "an ongoing project" means that the norms of this are being implemented, work in real practice, and determine the behavior of various social groups and individuals. The main goals of such a project are goals, norms, standards, programs, assessments.

The study of participatory and corporate-value design of the social environment from the standpoint of project knowledge involves identifying its basic conditions, without which the functioning of design in the social environment is impossible. These conditions are the subjects of participatory management, the practice of participatory, corporate value design as a practical activity to achieve goals (using the principle of involvement, creating a special value environment), relations between the subjects. Thus, the project approach, from the standpoint of management theory, lays the foundations for the creation of a theoretical concept and specific management decisions on the formation of an environment in an organization, a social local society in the process of developing an appropriate management project, as a type of prescriptive knowledge - a complex target image of changes in an organization (school), or a local society (ZATO) in the future, which presupposes a program of concrete actions for its implementation.

Survey and guide interviews were used as empirical methods.

The interviews were conducted by the authors from October to November 2019-2020. The objects of the study were specialists in the field of general education of the city of Noyabrsk, Yamalo-Nenets Autonomous Okrug (target selection, the total number of respondents was 24 , including heads of secondary schools $(\mathrm{N}=8)$, employees of the Department of Education of Noyabrsk $(\mathrm{N}=4)$, representatives of public organizations, including social non-commerce organizations - SoNCO $(\mathrm{N}=3)$, teachers of educational 
institutions $(\mathrm{N}=9)$. The research was of a qualitative nature, and in the presented report the emphasis is on the "live" statements of the respondents. Each conclusion, generalization, remark or statement transcribed and corroborated with appropriate quotations from the transcripts of the audio recording of the interview;

The survey was organized in 2018-2020. in UEHK, Administration of closed cities ZATO Novouralsk, ZATO Novouralsk. Quantitative survey methods were used (target sample, $\mathrm{N}=600)$.

\section{Results}

\subsection{Opportunities and features of participatory (involved) design in a modern school}

In 2019-2020 the team of authors with the participation of E.V. Aleshina and A.I. Zverev organized a sociological study on the topic "Subjects of the educational process about design in the management system of a secondary education institution" in order to conduct a series of gad-interviews. The situation in the area under study and the formulation of the problem were characterized as follows. A significant problem of modern secondary school is the quality of education, which is expressed in direct quantitative indicators:

- the quality of academic performance, USE, OGE, VPR;

- the effectiveness of participation in Olympiads and competitions;

- the number of medalists;

- indicators of admission of graduates to universities;

- involvement of teachers and students in various social initiatives;

- the level of education and socialization of students.

Indirect indicators are in this case:

- the activity of the parent community;

- school-wide rating within the framework of various grading systems;

- the demand for a secondary education institution, the image of a specific secondary school in a city, region, etc.

High direct and indirect indicators indicate a high quality of education. Low - on the contrary. Most of these indicators correlate with the presence and level of formation in the school of the conditions necessary for this. We call the totality of such conditions "an active educational and upbringing environment for development."

Social design, organized according to the principle of participation, is capable of ensuring the creation and development of this environment. That is, the inclusion of representatives of stakeholders in this process and the organization of effective interaction between them in the creation, implementation of school social projects, as well as control and subsequent assessment of the results of social design.

The object of the study was the opinions of the subjects of the educational process teachers, school leaders, parents and students on the subject of assessing the use of social design in the framework of school relationships, personal experience of participation in it.

In the course of the study, the following results were obtained for several problematic blocks of designing the educational environment of a general education institution.

1. The specific features of the use of design in secondary school for the formation of an educational and educational environment have been identified:

- a school project is understood by experts in different ways: as an independent assessment task, team activity to solve a school problem, a kind of school (one-time or repetitive) event. That is, not in the managerial sense that is stated in the first chapter of the 
dissertation, but rather at an ordinary level. In any case, projects are characterized by the presence of a topic, deadlines and evaluation of results.

- a child and an adult are recognized as equal participants in the project, but only taking into account objective age factors. Children and adults help each other: children offer a fresh perspective on the world, their opinions are taken into account, and adults share their experiences.

- it is noted that the key participants in school projects should be the students themselves, ideas, ideas for implementation should come from themselves. The circle of participants is wide and is not limited only to the teacher and students. Tasks of adults: primary interest, support initiatives, help them with the organization, "infect with the idea", captivate, "ignite". An effective project involves working on a solution to a problem common to all participants, as well as the presence of an initiative person or group.

- the importance of the participation of parents in school activities-projects is noted. The main advantages of parental involvement for children, parents, schools are in improving family relationships: the ability to get closer to your child, participate in his life, understand him better, solve his problems; participation in school life and solving school problems: enriching the school environment with their ideas, the possibility of introducing new traditions.

- the opportunity to plan school activities-projects is seen in different ways also for extracurricular hours: after lessons, on weekends, holidays, it is not worth it, because it interferes with recovery after school. It is worth it because there is an opportunity for full participation, without distractions. But at the same time, it is necessary to take into account the employment of schoolchildren in the system of additional education.

2. It has been substantiated that the design of the educational environment is the practical technology that can give the desired result in the educational institution.

- significant advantages of design and the possibility of solving school problems are noted. In particular, projects form in their participants such social competencies as goal-setting, independence, planning skills, posing and solving problems, teamwork, focus on personal growth and career guidance. If a school event-project directly affects the interests of its participants, then motivation, involvement in the process, understanding and empathy are significantly increased.

- designing at school on an ongoing basis implements an important social function, since it represents all the conditions for the formation of traditions and an integral personality (not only children, but also adults), conditioning the emergence of an active educational and educational environment for the development of all participants in school relationships.

- among the specific practical results of the application of design at school, based on the personal experience of experts, the following are noted: the possibility of children forming their own, "author's" conclusions; training in independence, better knowledge of information, obtaining practical knowledge, working out and rethinking school problems; gaining practical experience of communication with adults and peers on the example of joint socially significant activities and mastering the skills to achieve success; creating a positive school atmosphere of cooperation and mutual understanding, solidarity, involvement in the life of the school - a participatory educational and educational environment.

- one of the main roles in creating (coming up with interesting ideas) and carrying out school activities-projects should be played by the students themselves, offering their ideas; independently implementing them with the support of adults, children acquire an understanding of their importance in the project, in the life of the school, develop a sense of responsibility, and become involved in school life. The role of an adult in a school project is the role of a tutor, a curator for children. 
3. The main problem areas in the context of various social groups of respondents that were identified during the study are as follows:

- parents do not see children as equal participants with adults and are inclined, in fact, to limit their rights in designing;

- children do not want their parents to be involved in their school life;

- on the part of school workers, authoritarianism manifests itself, as a desire to take the design management into their own hands, which can be justified by the need, from their point of view, to establish the missing contact between children and adults, which is necessary for effective design:

- with regard to the application of design technology: the possibility of involving only senior students in the project; lack of self-organization skills in children; different interests of adults and children in life and joint detail; low priority of the dissemination of design in the school, along with other tasks.

\subsection{Closed cities as an object and a result of corporate value design}

In 2018-2020. CM. Karachkov and A.I. Zverev organized a series of sociological surveys, the purpose of which was to identify the role of social design in the formation of the corporate value core of the urban environment of nuclear-powered ZATOs (SC "Rosatom"). At the moment, a difficult situation has developed around the ZATO: on the one hand, the closed cities managed to preserve a lot of Soviet developments and corporate values, the corporate spirit of the participants in the Soviet atomic project, on the other hand, ZATOs are going through a post-project period of development; the goals that were initially set for them (ensuring nuclear parity in the Cold War) are no longer relevant, but ZATOs have formed as urban societies and are forced to integrate into existing regional, municipal systems without sufficient resources and competencies. As one of the development concepts, it was proposed to use the corporate value potential of the core of the urban environment of the closed city for a post-project reboot.

The object of the study was the opinions of the group actors of the social environment of the closed administrative territorial entities - residents, the management of the cityforming enterprises of the State Atomic Energy Corporation "Rosatom", representatives of public associations and activists with a view to identifying the design nature of the creation and development of the value core of corporatism.

The following manifestations in the relationships of group actors in the social environment of closed cities can be considered indicators of corporatism as a core value:

- a unified view of the directions of development of closed cities;

- demonstration of social identity in terms of the "spirit of cohesion", the awareness that the residents of the ZATO perform an important state task, "are bound by one goal," "do one thing," etc .;

- feeling like representatives of a unique group of "residents of closed cities", a community of professionals, etc .;

According to the results of the conducted surveys, the authors received the following results.

1. In general, it can be said that the residents of ZATO consider their city unique. (more than $60 \%$ of the total number of respondents, in the older age group - more than $70 \%$.) Today, 30 years have passed since the transition of ZATO to the post-project stage of development. Thus, the current older generation is middle-aged residents of ZATO at the time of the completion of the atomic project. Young people feel their otherness indirectly, since corporate values have been passed on to them from their families. The rest of the urban environment practically does not broadcast them directly (except for the ZATO regime, they are increasingly similar to ordinary Russian small towns). 
2. The respondents are not sure about the positive future of ZATO, their preservation of the status of "elite" cities of Russia. It is not clear whether ZATOs will again be in the same demand as centers of intellectual and technological development, ensuring national defense potential, in the spirit of corporatism, whether they will again find themselves "at the forefront" of solving an important state problem, etc. whether the closed territorial system has its own status, which was established in the USSR? " 36\% answered positively, $16 \%$ negatively, $48 \%$ found it difficult to answer. At the same time, young people found it more difficult (almost $60 \%$ of the total number of respondents by subgroup). An explanation of the possible reasons for such a vision of the problem by the respondents is noted in the work of S.M. Karachkov, "the Ural" nuclear "cities are going through a serious systemic crisis, so it is not completely clear what their essence is today, what is their place in the system of state, industrial relations in modern Russia. On the one hand, sufficient production, technical, intellectual and cultural potential has been accumulated and preserved for the implementation of various defense-strategic, innovative national tasks, on the other hand, the residents of the closed administrative territorial entities feel the ambiguity of the position of the state and big business (Rosatom) regarding the forms of support and content subsidized infrastructure of the former Soviet "atomic" special projects "[12]. Obviously, the project status of the creation and development of ZATO presupposed, on the one hand, the external cultivation of the corporate value core of the identity of the ZATO residents (propaganda, supply, other confirmations of the "elite status"), on the other hand, such a structure of the organization of relationships determined the spread of elements of the value yarn of corporatism at the educational level, education, not only school, but also family. We should also mention the popularization of the idea of professional dynasties in ZATOs as a factor in the spread and entrenchment of corporatism in the ZATO environment. All these tools must be considered as project ones, since a complex target image is clearly distinguished (ZATO is as an elite city-combine that solves a primary state task), a clearly formed governing entity ("Special Committee under the Council of Ministers of the USSR consisting of L.P. Beria - head of the NKVD, chairman, general management, intelligence, counterintelligence in the framework of the atomic project; M.G. Pervukhin - People's Commissar for Khimprom, Deputy, general oversight of activities as agreed by the project participants; G.M. Malenkov - Secretary of the Central Committee of the All-Union Communist Party (b), overseeing the party and personnel work within the project; N.A. Voznesensky - Chairman of the State Planning Committee of the USSR, overseeing planning and economic activities within the project; B.L. Vannikov People's Commissar of Ammunition, Head of the First Main Directorate of the Council of Ministers of the USSR, overseeing industrial activities within the framework of the project; Zavenyagin A. P. - Deputy People's Commissar of Internal Affairs, overseeing engineering activities within the project; I. V. Kurchatov - Head of the Laboratory and No. 2 of the USSR Academy of Sciences, scientific leader of the project, solving scientific problems, supervising the activities of researchers in related branches of science, managing the laboratory; V.A. Makhnev - Head of the Secretariat of the Commission, overseeing the maintenance of technical documentation for the project "[13].

3. The characteristic features of a closed administrative territorial entity include "high intellectual level of the population", "implementation of a strategic, nationally important task", "security, safety and comfort, on the one hand, serious restrictions on the other; higher indicators of social security". At the same time, young people to a greater extent note the comfort of safe living and at the same time certain restrictions associated with the regime status $(56 \%)$, and the older generation, who have experience of living during the period of active development of ZATOs, still associates the corporative nature of ZATOs, mainly with the implementation of closed cities of the global task of ensuring national security. 
At the same time, S.M. Karachkov in his earlier studies of 2012-2016. noted that the state strategic goal by the residents of ZATO "is most often implied, but more often as something abstract, not related to concrete reality, that is, it goes into an abstract-value block, is excluded from everyday work, communication practice (this is not spoken about at work, in the family circle, this is not in the air, it seems to be implied by itself) "[12].

4. An indicator of the use of design for the formation of the corporate character of the value core of the residents of the closed city may be the difference in the perception of the nature of the regime among the representatives of the older generation and young people. The older generation perceives the regime as a necessary condition, a consequence of the fulfillment of an important state task. Youth, as an initially self-valuable attribute of a closed city, that is, out of touch with the main goal of creating a closed city. Moreover, in the respondents' answers, "the implementation of an important state task" is less and less noted as an attribute of the closed administrative system, depending on age. These regularities are confirmed by the fact that in the post-project stage, any project activity in relation to the development of closed administrative cities was curtailed and the project influence on the core of corporate values became minimal.

5. Regarding the spirit of cohesion as an indicator of the corporative nature of closed cities, the survey clearly demonstrated that residents of closed cities do not directly feel the spirit of cohesion, there is no obvious "atmosphere of unity". This largely reflects the allRussian trend. So, V.A. Kasamara and A.A. Sorokin attributed this to "the phenomenon of post-Soviet nostalgia" in the everyday discourse of Russians. They write the following: "Nostalgia for the Soviet Union is associated with three main reasons that were mentioned by the respondents, regardless of whether they lived in this state or were born during or after perestroika and did not have time to catch Soviet times. The first reason is associated with the need for an order that is interpreted quite broadly - from the opportunity not to be afraid to go out to the presence of labor discipline, when no one is late for work and fully complies with all formal norms and rules. In addition, the respondents revealed the need for a friendly psychological atmosphere, when people trust each other and are ready to help. The atmosphere of mutual assistance and cohesion, according to the respondents, was in the USSR and is completely absent in modern Russia"[14]. In his early studies, S.M. Karachkov and A.I. Zverev noted the following: "the inhabitants of ZATO, by nature" greenhouse "townspeople, demonstrate a lack of an atmosphere of cohesion, and this is not a statement of absence, but rather an expression of the fact that in the USSR the spirit of cohesion was much stronger than it is now. In contrast, the townspeople perceive the decline in the level very painfully, and the older generation - by personal example, the younger, especially students - in the course of reproduction (by inertia) of the opinion of the older generation ... During the survey, the respondents were asked an open question: what, in their opinion, specifically is the cohesion of ZATO residents expressed (if they noted that they feel a sense of cohesion)? Here are the most frequently encountered answers in descending order of importance (the number of similar answers): (1) Feeling of safety "behind the fence"; (2) Devotion to one's business and enterprise, desire to preserve the appearance and former status of the city; (3) General goals; (4) Implementation of a strategically important task in the national plan; (5) Desire to make your city more comfortable for living, highly educated, etc .; (6) Desire to see the city clean and beautiful; (7) Respect for urban traditions; (8) Everyone knows each other "[12].

\section{Conclusions}

The project approach is actually being developed within the framework of individual theoretical studies, and is also widely used in the practice of social management at the level of an organization, a municipality, a region, and the state. At the same time, the theory 
lacks the systematization of disparate provisions, concepts, ideas into a single methodological approach, the development of a clear terminological apparatus, etc. Proceeding from this, the practical design experience is formed largely situationally, without a proper scientific, methodological, instrumental base, is subjective, personalized character (that is, it depends mainly on the personality and the governing subject). There is no interdisciplinary exchange of experience and developments both at a theoretical and practical level. Economists, political scientists, sociologists, and philosophers do not work together to develop a method. Organizational management practitioners do not share their best practices with experts in the field of urban studies; the tradition of designing in the field of state and municipal management generally "stands alone" (see national projects, programs and roadmaps for the development of key areas). The experience presented in this article demonstrates the scientific and practical prospects of applying the design approach, including within the framework of the concept of participatory (involved) and corporate value design.

\section{References}

1. B. N. Gerasimov, Development of organizational design methodology in management activities, Bulletin of the Samara University. Economics and Management, 3 (2018). Access mode: https://cyberleninka.ru/article/n/razvitie-metodologii-organizatsionnogoproektirovaniya-v-upravlencheskoy-deyatelnosti

2. L. Zhu, S. O. Cheung, Harvesting Competitiveness through Building Organizational Innovation Capacity, Journal of Management in Engineering, 33 (5), 04017020 (2017)

3. B. N. Gerasimov, K. B. Gerasimov, Management of economic systems (INFRA-M, 2016)

4. N. V. Mironenko, O. V. Leonova, Evolution of project management development in Russia and abroad, Management consulting, 6 (102) (2017). Access mode: https://cyberleninka.ru/article/n/evolyutsiya-razvitiya-proektnogo-upravleniya-v-rossiii-za-rubezhom

5. B. N. Porfiriev, Imperatives of legislative support for the implementation of the May 2018 Decree of the President of Russia: a spatial aspect, Eco., 9 (531), 177-191 (2018). Access mode: https://elibrary.ru/item.asp?id=35594237

6. O. B. Ivanov, E. M. Buchwald, Investment priorities in strategies of socio-economic development of Russian regions, ETAP: Economic Theory, Analysis, Practice, 2, 3147 (2018). Access mode: https://doi.org/10.24411/2071-6435-2018-10014

7. R. L. Fedosova, Experience and results of the implementation of national projects in Russia, Strategic management: theory, practice and problems, 115-121 (2018). Access mode: https://elibrary.ru/item.asp?id=34943498

8. N. N. Bondareva, N. I. Komkov, Organizational and methodological issues of development and implementation of national projects, MIR (Modernization. Innovation. Development), 3 (2019). Access mode: https://cyberleninka.ru/article/n/organizatsionno-metodicheskie-voprosy-razrabotki-irealizatsii-natsionalnyh-proektov

9. S. A. Makovkina, O. M. Trofimova, Implementation of project management standards in state and municipal management, Management issues, 4 (2016). Access mode: http://vestnik.uapa.ru/ru/issue/2016/04/7

10. G. P. Shchedrovitsky, Selected Works (School of cultural policy, 1995)

11. R. Ackoff, Planning the future of the corporation (1985). Access mode: 
https://www.lib-bkm.ru/14155 (date of treatment 08/20/2020)

12. S. M. Karachkov, Corporate model of social management of a closed "atomic" city: dissertation ... candidate of sociological sciences: 22.00 .08 (2014)

13. History of the Soviet atomic project, RIA Novosti (2010). Access mode: https://ria.ru/20100201/207163686.html

14. V. A. Kasamara, A. A. Sorokina, Post-Soviet nostalgia in the everyday discourse of Russians, Social sciences and modernity, 6 (2011). Access mode: http://www.hse.ru/data/2012/03/06/1270362642/Postsovetskaya_nostaligiya.pdf 